\title{
Analisis Pembiayaan Mudharabah Terhadap Peningkatan Laba Bersih Pada PT. Bank Perkreditan Rakyat Syariah Amanah Insan Cita William Iskandar Medan
}

\author{
Muslih \\ Fakultas Ekonomi dan Bisnis, Universitas Muhammadiyah Sumatera Utara \\ Email: muslihekonomi@gmail.com
}

\begin{abstract}
ABSTRAK
Penelitian ini bertujuan untuk mengetahui (1) bagaimana pembiayaan mudharabah di PT. BPR Syariah Amanah Insan Cita, (2) untuk mengetahui mengapa pembiayaan mudharabah menurun pada tahun 2015, (3) untuk mengetahui kemampuan pembiayaan mudharabah dalam menghasilkan laba pada PT. BPR Syariah Amanah Insan Cita William Iskandar Medan. Metode yang digunakan dalam penelitian ini adalah deskriptif analisis dengan pendekatan studi kasus. Teknik pengumpulan data dilakukan melalui data primer yaitu data yang diperoleh langsung dari sumber data dimana penelitian ini dilaksanakan di PT. BPR Syariah Amanah Insan Cita William Iskandar Medan dan data sekunder yaitu data yang diperoleh dari literatur dan buku-buku yang ada hubungannya dengan masalah yang akan diteliti. Alat analisis yang digunakan adalah analisis trend. Hasil penelitian menunjukkan bahwa kemampuan pembiayaan mudharabah dalam menghasilkan laba dapat dikatakan mampu untuk meningkatkan laba bagi perusahaan walaupun pembiayaan menurun tapi laba yang dihasilkan tetap meningkat. pembiayaan mudharabah memiliki kemampuan yg signifikan dalam meningkatkan laba bersih bagi perusahaan.
\end{abstract}

Kata Kunci: Pembiayaan Mudharabah dan Laba Bersih

\section{Mudharabah Financing Analysis To Increase Netto Income at PT. Bank Perkreditan Rakyat Syariah Insan Cinta William Iskandar Medan}

\begin{abstract}
This study aims to determine (1) how mudharabah financing in PT. BPR Syariah Amanah Insan Cita, (2) to find out why mudharabah financing decreases in 2015, (3) to know the ability of mudharabah financing in generating profit at PT. BPR Syariah Amanah Insan Cita William Iskandar Medan. The method used in this research is descriptive analysis with case study approach. The technique of collecting data is done through primary data that is data obtained directly from the data source where this research conducted at PT. BPR Syariah Amanah Insan Cita William Iskandar Medan and secondary data are data obtained from the literature and books that have to do with the problem to be studied. The analysis tool used is trend analysis. The results showed that the ability of mudharabah financing in generating profits can be said to be able to increase profits for the company although the financing decreased the profit generated increased. mudharabah financing has a significant ability to increase net income for the company.
\end{abstract}

Keywords: Mudharabah Financing and Net Income.

How to cite:

Muslih. (2017). Analisis Pembiayaan Mudharabah Terhadap Peningkatan Laba Bersih Pada PT. Bank Perkreditan Rakyat Syariah Amanah Insan Cita William Iskandar Medan. Jurnal Ilmiah Manajemen \& Bisnis, 18(1), 73-88 


\section{PENDAHULUAN}

Saat ini perkembangan keuangan syariah (financial market sharia) sedang marak di dunia, khususnya di negara-negara yang mayoritas penduduk muslim. Hal ini ditandai dengan berdirinya Islamic Financial Market di Kuala Lumpur yang dipelopori negara-negara islam. Bank syariah lahir dengan konsep dan filosofi interest free, yang melarang penerapan bunga dalam semua transaksi perbankan karena termasuk kategori riba. Perbankan syariah di Indonesia tengah menjamur dimana-mana, akan tetapi pemahaman masyarakat Indonesia tentang perbankan syariah masih kurang, sehingga masyarakat lebih memilih untuk bertransaksi pada bank konvensional. Hal ini dipertegas oleh Ali (2010,hal. 17) ia menyatakan bahwa:"Perbankan syariah bila dilihat dari aset dapat dikatakan bahwa telah mengalami pertumbuhan yang sangat pesat, yaitu sebesar $74 \%$ pertahun selama kurun waktu 1998 sampai 2001 (nominal dari Rp. 479 miliar pada tahun 1998 menjadi 2.178 miliar pada tahun 2001). Selain itu dana pihak ketiga telah meningkat dari Rp. 392 miliar menjadi Rp. 1.806 miliar. Oleh karena itu, sistem perbankan syariah telah mengalami pertumbuhan dalam hal kelembagaan, yaitu jumlah bank umum syariah telah meningkat dari 1 (satu) bank umum syariah, 78 BPRS pada tahun 1998 menjadi 2 (dua) bank umum syariah, 3 (tiga) unit usaha syariah (UUS) dan 81 BPRS pada akhir tahun 2001. Jumlah kantor cabang dari bank umum syariah dan UUS dari 26 telah meningkat menjadi 51 kantor".

Pengharaman riba memunculkan kebutuhan kepada alternatif produk dan pelayanan perbankan yang sesuai dengan syariah islam. Bank syariah menawarkan alternatif produk dan jasa perbankan tanpa mengandung riba. Salah satu bentuk jasa perbankan syariah yang paling sering digunakan adalah sistem pembiayaan dengan akad mudharabah, serta akad jual beli seperti murabahah. Hal ini sejalan dengan Kasmir (2010, hal. 27) bahwa: Prinsip syariah yang diterapkan bank syariah adalah pembiayaan berdasarkan prinsip bagi hasil (mudharabah), pembiayaan berdasarkan penyertaan modal (musyrakah), prinsip jual beli barang dengan memperoleh keuntungan (murabahah), atau pembiayaan barang modal berdasarkan prinsip sewa murni tanpa pilihan (ijarah) atau dengan adanya pilihan pemindahan atas barang yang disewa dari pihak bank oleh pihak lain (ijarah wa istisnha).

Menurut Soemitra (2010, hal.335) "pembiayaan berdasarkan prinsip syariah adalah pembiayaan berdasarkan persetujuan atau kesepakatan antara perusahaan pembiayaan dengan pihak lain yang mewajibkan pihak yang dibiayai untuk mengembalikan pembiayaan tersebut dalam jangka waktu tertentu dengan imbalan atau bagi hasil". Pembiayaan yang berdasarkan prinsip syariah ini merupakan prinsip pembiayaan yang baik bagi masyarakat atau konsumen.

Dengan adanya pembiayaan tersebut diharapkan mampu memacu masyarakat untuk bisa menciptakan usaha dan mampu mengembangkannya. Tidak hanya itu pembiayaan yang dilakukan oleh bank syariah menuntut kejujuran dari kedua pihak, hal ini tentu akan menciptakan kenyamanan dalam menjalin kerjasama.

Tabel 1 Data Pembiayaan Mudharabah dan Murabahah

\begin{tabular}{|c|c|c|}
\hline Tahun & Mudharabah & Murabahah \\
\hline 2011 & Rp.100.000.000 & Rp. 3.245.340.000 \\
\hline 2012 & Rp.181.000.000 & Rp. 4.469 .830 .000 \\
\hline 2013 & Rp. 302.000 .000 & Rp. 6.375.624.000 \\
\hline 2014 & Rp. 756.642.000 & Rp. 8.784.156.000 \\
\hline 2015 & Rp. 615.000 .000 & Rp.12.175.110.000 \\
\hline
\end{tabular}


Pada tabel diatas dapat kita lihat ada 2 pembiayaan yang dikontribusikan dalam lima periode yaitu mulai dari tahun 20112015, dimana pembiayaan terdiri dari pembiayaan mudharabah dan murabahah. Disini peneliti hanya berfokus pada pembiayaan mudharabah sesuai variabel judul pembiayaan mudharabah dari tahun 2011-2015 yang mengalami penurunan ditahun 2015. Ditahun 2011 mengalami kenaikan menjadi 181 juta ditahun 2012, di tahun 2013 naik kembali menjadi 302 juta, di tahun 2014 kembali naik lagi menjadi 756.642 ribu. Namun ditahun 2015 mengalami penurunan menjadi 615 juta.

Berdasarkan data tabel diatas sesuai dengan variabel judul yaitu pembiayaan mudharabah dapat diindikasikan bahwasanya fenomena yang terjadi ialah penurunan pembiayaan mudharabah ditahun 2015 yang akan berkonsekuensi pada salah satu penurunan pendapatan (bagi hasil mudharabah) dari penyaluran pembiayaan mudharabah. Dan apabila sebaliknya data yang ada terus meningkat otomatis pendapatan akan meningkat. Karena kita ketahui semakin banyak modal (mudharabah) yang disalurkan atau yang dikeluarkan maka daya produksi (proyek) maka semakin tinggi dan otomatis penghasilan meningkat. Dan sebaliknya semakin sedikit modal (mudharabah) yang disalurkan maka kapasitas produksi (proyek) maka semakin menurun dan penghasilan yang diperoleh semakin rendah. Mungkin karena pembiayaan ini sangat membutuhkan kepercayaan yang tinggi dan sangat beresiko, penyaluran pembiayaan mudharabah mengalami penurunan.

Namun sejauh ini pengelolaan pembiayaan Mudharabah masih belum banyak dikembangkan oleh sebagian bankbank syariah. Oleh karena itu pengetahuan masyarakat mengenai pembiayaan Mudharabah ini masih minim. Dalam Bank Syariah khususnya di BPR Syariah Amanah Insan Cita penggunanaan pembiayaan berprinsip Mudharabah juga masih kalah dengan pembiayaan Murabahah. Produk pembiayaan berprinsip jual beli (Murabahah) disalurkan kepada nasabah untuk kebutuhan konsumsi yang mana ruang lingkup kebutuhan ini lebih luas dibandingkan dengan pembiayaan Mudharabah dengan ruang lingkup pengusaha. Hal ini terjadi karena Bank Syariah menilai pembiayaan Murabahah lebih menguntungkan. Karena produk Murabahah menggunakan marjin sebagai keuntungan bank Syariah yang mana marjin sudah ditentukan besarnya oleh bank syariah di awal akad. Dengan demikian produk Murabahah tidak membawa resiko kerugian bagi bank syariah.

Sementara itu pembiayaan Mudharabah tidak bisa dihindarkan dengan resiko ketidakpastian. Hal ini karena Mudharabah menggunakan prinsip bagi hasil atau bagi keuntungan, yang mana keuntungan yang didapatkan oleh nasabah atau pengusaha tidak selalu konstan tiap bulannya. Resiko ini menjadi alasan bankbank syariah jarang menggunakan produk ini dalam penyaluran pembiayaannya. Resiko kerugian ini bisa diminimalkan dengan analisa 5C (Character, Capacity, Capital, Collateral \& Condition). Dengan analisa yang tepat oleh bank terhadap calon nasabah yang baik, bank syariah dapat mengetahui prospek usaha yang dilakukan oleh calon nasabah (2008, hal. 108-111)

\section{KAJIAN TEORI}

Perbankan dalam kehidupan suatu negara adalah salah satu agen pembangunan (agent of development). Hal ini dikarenakan adanya fungsi utama dari perbankan itu sendiri sebagai lembaga yang menghimpun dana dari masyarakat dalam bentuk simpanan dan menyalurkan kembali kepada masyarakat dalam bentuk pembiayaan.

Eksistensi lembaga keuangan khususnya sektor perbankan menempati posisi sangat strategis dalam menjembatani kebutuhan modal kerja dan investasi sektor real dengan pemilik dana. Dengan demikian 
fungsi utama dari sektor perbankan dalam infrasturktur kebijakan makro ekonomi memang diarahkan dalam konteks bagaimana menjadikan uang efektif untuk meningkatkan nilai tambah ekonomi.

Keberadaan perbankan syariah di Indonesia merupakan perwujudan dari keinginan masyarakat yang membutuhkan suatu sistem perbankan alternatif yang menyediakan jasa perbankan yang memenuhi prinsip syariah. Keberadaan bank syariah secara formal dimulai sejak dibuatnya Undang-Undang Nomor 7 Tahun 1992 Tentang Perbankan (Lembaran Negara Republik Indonesia Tahun 1992 Nomor 31, Tambahan Lembaran Nomor 3472) walaupun istilah yang dipakai adalah pembiayaan yang berdasarkan pada prinsip bagi hasil, namun pembiayaan bagi hasil mengarah pada produk-produk bank syariah salah satu produknya yaitu pembiayaan Mudharabah.

Menurut Rodoni dan Hamid (2011, hal. 15) "Bank syariah adalah bank yang dalam aktivitasnya baik dalam penghimpunan dan maupun dalam rangka penyaluran dananya memberikan dan mengenakan imbalan atas dasar prinsip syariah". Pada dasarnya ketiga fungsi utama perbankan (menerima titipan dana, meminjamkan uang, dan jasa pengiriman uang) adalah boleh dilakukan kecuali bila dalam pelaksanaan fungsi perbankan melakukan hal-hal yang dilarang syariah. Hal ini sejalan dengan pendapat Ali (2010, hal. 1) ia mengemukakan bahwa: "bank syariah terdiri atas dua kata, yaitu (a) bank dan (b) syariah, Kata bank bermakna suatu lembaga keuangan yang berfungsi sebagai perantara keuangan dari dua pihak, yaitu pihak yang berkelebihan dana dan pihak yang berkekurangan dana. Kata syariah dalam versi bank syariah di Indonesia adalah aturan perjanjian berdasarkan yang dilakukan oleh pihak bank dan pihak lain untuk penyimpanan dana dan/atau pembiayaan kegiatan usaha dan kegiatan lainnya sesuai dengan hukum islam.
Penggabungan kedua kata dimaksud menjadi "bank syariah" bank syariah adalah suatu lembaga keuangan yang berfungsi sebagai perantara bagi pihak yang berkelebihan dana dengan pihak yang kekurangan dana untuk kegiatan usaha dan kegiatan lainnya sesuai dengan hukum islam".

Dari pengertian di atas dapat disimpulkan bahwa Bank Syariah adalah badan usaha yang menghimpun dana dari masyarakat dalam bentuk simpanan dan menyalurkannya kepada masyarakat dalam bentuk pembiayaan dan atau bentuk lainnya berdasarkan prinsip syariah yang dalam kegiatannya. Sejalan dengan pendapat diatas Lubis dan Wajdi (2012, hal.49 ) menjelaskan bahwa:

Bank syariah adalah bank yang pengoperasiannya disesuaikan dengan prinsip syariat islam, banyak istilah yang diberikan untuk menyebut entitas bank Islam, ada yang menyebut Bank Tanpa Bunga (Interest Free Bank) Bnak Tanpa Riba (Lariba Bank, dan Bank Syariah”.

\section{Fungsi dan Peran Bank Syariah}

Sistem lembaga keuangan atau yang lebih khusus lagi disebut sebagai aturan yang menyangkut aspek keuangan dalam sistem mekanisme keuangan suatu negara telah menjadi instrument penting dalam mempelancar jalannya pembangunan suatu bangsa, Indonesia yang mayoritas penduduknya beragama islam tentu saja menuntut adanya sistem baku yang mengatur dalam kegiatan kehidupannya. Termasuk diantaranya kegiatan keuangan yang di jalankan oleh setiap umat. Keberadaan islam di tanah air telah mendapatkan pijakan kokoh setelah lahirnya Undang-Undang Perbankan Nomor 7 tahun 1992 yang direvisi melalui Undang- Undang Nomor 10 tahun 1998, yang mengakui keberadaan dan fungsinya bank bagi hasil atau bank islam.

Menurut Soemitra (2009, hal.67) Bank Syariah bukan sekedar bank bebas 
bunga, tetapi juga memiliki orientasi pencapaian kesejahteraan. Secara funda mental terdapat beberapa karakteristik bank syariah:

1. penghapusan riba.

2. Pelayanan kepada kepentingan publik dan merelisasikan sasaran sosioekonomi islam.

3. Bank syariah bersifat universal yang merupakan gabungan dari bank komersil dan bank investasi.

4. Bank syariah cenderung mempererat hubungan antara bank syariah dan pengusaha.

\section{Pengertian Pembiayaan}

Menurut Peraturan Otoritas Jasa Keuangan tahun 2014 pasal (1) ayat 10 "Pembiayaan adalah kesepakatan tertulis antara Bank Syariah dengan pihak lain yang memuat adanya hak dan kewajiban masingmasing pihak sesuai dengan prinsip syariah". Hal ini sependapat denganMuhammad (2014,hal.40) bahwa "Pembiayaan adalah penyedia dana atau tagihan yang dipersamakan dengan itu berupa:

1. Transaksi bagi hasil dalam bentuk Mudharabah dan musyarakah.

2. Transaksi sewa menyewa dalam bentuk ijarah.

3. Transaksi jual beli dalam bentuk piutang murabahah dan istishna'.

4. Transaksi pinjam meminjam dalam bentuk qordh.

Adapun Menurut Kasmir (2004, hal. 98-99) unsur yang terkandung dalam pembiayaan yaitu:

1) Kepercayaan

Yaitu keyakinan pihak pemberi dana bahwa dana yang diberikan akan benarbenar dikembalikan dimasa yang akan datang.

2) Kesepakatan

Kesepakatan diwujudkan dalam bentuk perjanjian dimana masing pihak menandatangani hak dan kewajiban.

3) Jangka waktu
Jangka waktu mencakup masa panjang atau pendeknya pemberian dana harus dikembalikan.

4) Resiko

Resiko kerugian dapak diakibatkan dua yaitu kesengajaan nasabah yang tidak mau mengembalikan dana, padahal nasabah mampu untuk mengembalikan, dan karena terjadinya sebuah bencana atau kecelakaan sehingga nasabah benar.

5) Balas Jasa

Akibat dari pemberian pembiayaan atau kredit maka pihak penyedia dana mengharapkan suatu imbalan keuntungan dalam jumlah tertentu.

Dari definisi- definisi yang telah dijelaskan diatas maka jelaslah bahwa pembiayaan merupakan suatu pendanaan yang diberikan oleh pihak bank untuk memfasilitasi suatu usaha atau pihak-pihak yang membutuhkan (nasabah) yang didasarkan pada persetujuan atau kesepakatan antara kedua belah pihak sesuai dengan waktu yang telah ditentukan. Selain itu pembiayaan juga tidak sama dengan kredit meskipun ada sedikit kesamaan yaitu sama-sama menyalurkan dana kepada masyarakat akan tetapi di bank konvensional dana yang diberikan kepada nasabah tidak jelas arahnya, sedangkan pembiayaan di bank syariah nasabah benarbenar dikontrol tentang penggunaan dana untuk apa dan jenis usahanya selalu ditinjau oleh tim analisis bank, selain itu bank syariah juga lebih menguntungkan karena yang diberikan bank adalah keuntungan bersih dengan melihat presentase kesepakatan dari awal akad.

Dengan demikian pada saat pelaksanaan atau penerapan perjanjian masing-masing pihak yang mengadakan perjanjian atau yang mengikatkan diri dalam perjanjian haruslah mempunyai interpretasi yang sama tentang apa yang telah mereka perjanjikan. Menurut Kasmir (2008, hal. 108-111) dalam melakukan penilaian kriteria-kriteria serta aspek penilaiannya 
tetap sama. Biasanya kriteria penilaian yang harus dilakukan oleh bank untuk mendapatkan nasabah yang benar-benar menguntungkan dilakukan dengan analisis 5C dan 7P Adapun penjelasan untuk $5 \mathrm{C}$ sebagai berikut:

a) Character (karakter), suatu keyakinan bahwa sifat atau watak dari orang-orang yang akan diberikan pembiayaan benarbenar dapat dipercaya, hal ini tercermin dari latar belakang si nasabah, pekerjaan maupun yang bersifat pribadi seperti cara hidup yang dianutnya, keadaaan keluarga, hobi dan jiwa sosial.

b) Capacity (kemampuan), bisnis dihubungkan dengan tingkat pendidikan, kemampuan dalam memahami tentang ketentuan pemerintah dan tentu saja kemampuan menjalankan usaha, sehingga akan terlihat "kemampuannya" dalam mengembalikan pembiayaan yang disalurkan.

c) Capital (Modal Sendiri), untuk melihat penggunaan modal apakah efektif tercermin dari laporan keuangan (neraca dan laporan rugi laba) dengan melakukan pengukuran terhadap likuiditas, solvabilitas, rentabilitas dan ukuran lainnya, termasuk dari mana sumber permodalan yang ada.

d) Colleteral (Jaminan), diberikan calon nasabah baik yang bersifat fisik maupun non fisik. Jaminan hendaknya melebihi jumlah pembiayaan yang diberikan. Jaminan juga harus diteliti keabsahannya, sehingga jika terjadi suatu masalah, maka jaminan yang dititipkan akan dapat dipergunakan secepat mungkin.

e) Condition (Kondisi), dalam menilai pembiayaan hendaknya juga dinilai kondisi ekonomi dan politik sekarang dan dimasa yang akan datang sesuai sektor masingm masing, serta prospek usaha dari sektor yang ia jalankan.

Penilaian prospek bidang usaha yang dibiayai hendaknya benar-benar memiliki prospek yang baik, sehingga kemungkinan pembiayaan tersebut bermasalah relatif kecil. Penilaian pembiayaan dengan metode analisis $7 \mathrm{P}$ adalah sebagai berikut :

a) Personality, menilai nasabah dari segi kepribadiaanya atau tingkah lakunya sehari-hari maupun masa lalunya, mencakup sikap, emosi, tingkah laku dan tindakan nasabah dalam menghadapi suatu masalah.

b) Party, mengklasifikasikan nasabah ke dalam klasifikasi tertentu atau golongan-golongan tertentu berdasarkan modal, loyalitas serta karakternya.

c) Purpose, untuk mengetahui tujuan nasabah dalam mengambil pembiayaan, termasuk jenis pembiayaan yang diinginkan nasabah untuk modal kerja, konsumtif dan lainnya.

d) Prospect, menilai usaha nasabah dimasa yang akan datang menguntungkan atau tidak, atau dengan kata lain mempunnyai prospek atau sebaliknya. Hal ini penting mengingat bukan hanya bank yang rugi akan tetapi juga nasabah.

e) Payment, ukuran bagaimana cara nasabah mengembalikan pembiayaan yang telah di ambil atau dari sumber mana saja dana untuk mengembalikan pembiayaan.

f) Profitability, menganalisis bagaimana kemampuan nasabah dalam mencari laba. Profitabilitas diukur dari periode ke periode apakah akan tetap sama atau semakin meningkat, apalagi dengan tambahan pembiayaan yang akan di perolehnya.

g) Protection untuk bagaimana menjaga agar usaha dan jaminan mendapatkan perlindungan, dapat berupa jaminan barang atau orang atau jaminan asuransi.

\section{Poduk-produk BPR syariah}

Menurut Rodoni dan Hamid (2011, hal. 43-47) produk-produk yang ditawarkan oleh BPR Syariah secara garis besar adalah: 


\section{Dana Masyarakat}

a) Simpanan Amanah

Bank menerima titipan amanah berupa dana infaq,shadaqah, dan zakat.

b) Tabungan Wadi'ah

Bank menerima tabungan, baik pribadi maupun badan usaha dalam bentuk tabungan bebas.

c) Deposito Wadi'ah

Bank menerima deposito berjangka, baik pribadi maupun badan/lembaga.

\section{Penyaluran Dana}

a) Pembiayaan mudharabah

Suatu perjanjian antara pemilik dana (pengusaha) dengan pengelola dana (bank) yang keuntungan dibagi menurut rasio/nisbah yang telah disepakati bersama dimuka.

b) Pembiayaan musyarakah

Suatu perjanjian antara pengusaha dengan bank, dimana modal dari kedua bela pihak digabungkan untuk usaha tertentu yang dikelola secara bersama-sama, keuntungan dan kerugian ditanggung bersama sesuai dengan kesepakatan dimuka.

c) Pembiayaan bai bitsaman ajil

Proses jual beli antara bank dengan nasabah, dimana bank akan menalangi lebih dahulu kepada nasabah dalam pembelian suatu barang tertentu yang dibutuhkan kemudian nasabah akan membayar harga dasar barang dan keuntungan yang disepakati bersama.

d) Pembiayaan murabahah

Suatu perjanjian yang disepakati antara bank dengan nasabah, dimana bank menyediakan pembiayaan untuk pembelian bahan baku atau modal kerja lainnya yang dibutuhkan nasabah yang akan dibayar kembali oleh nasabah sebesar harga jual bank (harga beli bank plus margin keuntungan pada saat jatuh tempo).

e) Pembiayaan Qardhul Hasan

Suatu perjanjian antara bank dengan nasabah yang layak menerima pembiayaan kebajikan dimana nasabah yang menerima hanya membayar pokok yang dianjurkan.

\section{Jenis-jenis Mudharabah}

Dalam PSAK 105 Akuntansi

Mudharabah terbagi dalam 3 bagian yaitu:

1. Mudharabah muthlaqah adalah mudharabah dimana pemilik dana memberikan kebebasan kepada pengelola dana dalam pengelolaan investasinya.

2. Mudharabah muqayyadah adalah mudharabah dimana pemilik dana memberikan batasan kepada pengelola dana,antara lain mengenai tempat, cara dan atau obyek investasi.

3. Mudharabah musytarakah adalah bentuk mudharabah dimana pengelola dana menyertakan modal atau dananya dalam kerjasama investasi.

\section{a. Rukun dan Syarat Mudharabah}

Rukun adalah unsur yang mutlak harus dipenuhi dalam sesuatu hal, peristiwa dan tindakan. Sedangkan syarat adalah unsur yang harus ada untuk sesuatu hal, peristiwa dan tindakan tersebut. Menurut Ascarya (2008, hal. 62-63) Hal-hal yang menjadi rukun dan syarat dari pembiayaan mudharabah, antara lain:

a. Pelaku akad (shahibul maal) (pemodal) dan pengelola (mudharib).

b. Objek akad, yaitu modal (mal), kerja (dharabah), dan keuntungan (ribh) dan

c. Shighah, Yaitu Ijab dan Kabul

Syarat-syarat yang harus dipenuhi dalam mudharabah terdiri dari syarat modal dan keuntungan. Syarat modal yaitu:

1) Modal harus berupa uang

2) Modal harus jelas dan diketahui jumlahnya

3) Modal harus tunai bukan utang, dan

4) Modal harus diserahkan kepada mitra kerja

Sementara itu, syarat keuntungan, yaitu keuntungan harus jelas ukurannya dan keuntungan harus dengan pembagian yang disepakati kedua belah pihak. 


\section{b. Dasar Hukum Mudharabah}

Secara umum landasan dasar syariah mudharabah adalah:

1) Al- Qur'an: Surat Al- Maidah : 1

"Hai orang - orang yang beriman penuhilah akad - akad itu.

2) Al- Hadist

"Abbas bin Abdul Muthalib jika menyerahkan hartanya untuk mudharabah menetapkan syarat terhadap orang yang diberi modal untuk tidak menggunakan jalan laut dan tidak bermalam dilembah, tidak membeli hewan yang mempunyai penyakit paru - paru basah, jika menyalahi aturan maka mudharib menanggung atas dana (kerugian) tersebut. Maka telah sampai kepada Rasulullah syarat - syarat yang telah ditetapkan oleh Abbas dan Rasulullah membolehkannya. "(HR Thabrani). "Dari Shalih bin Shuhaib r.a. bahwa Rasulullah saw, bersabda, "tiga hal didalamnya terdapat keberkahan : pertama menjual dengan pembayaran secara tangguh,kedua muqharadah (mudharabah), dan ketiga mencampur gandum dengan tepung untuk keperluan rumah dan bukan untuk dijual."( HR Ibnu Majah no. 2280, kitab at Tijarah).

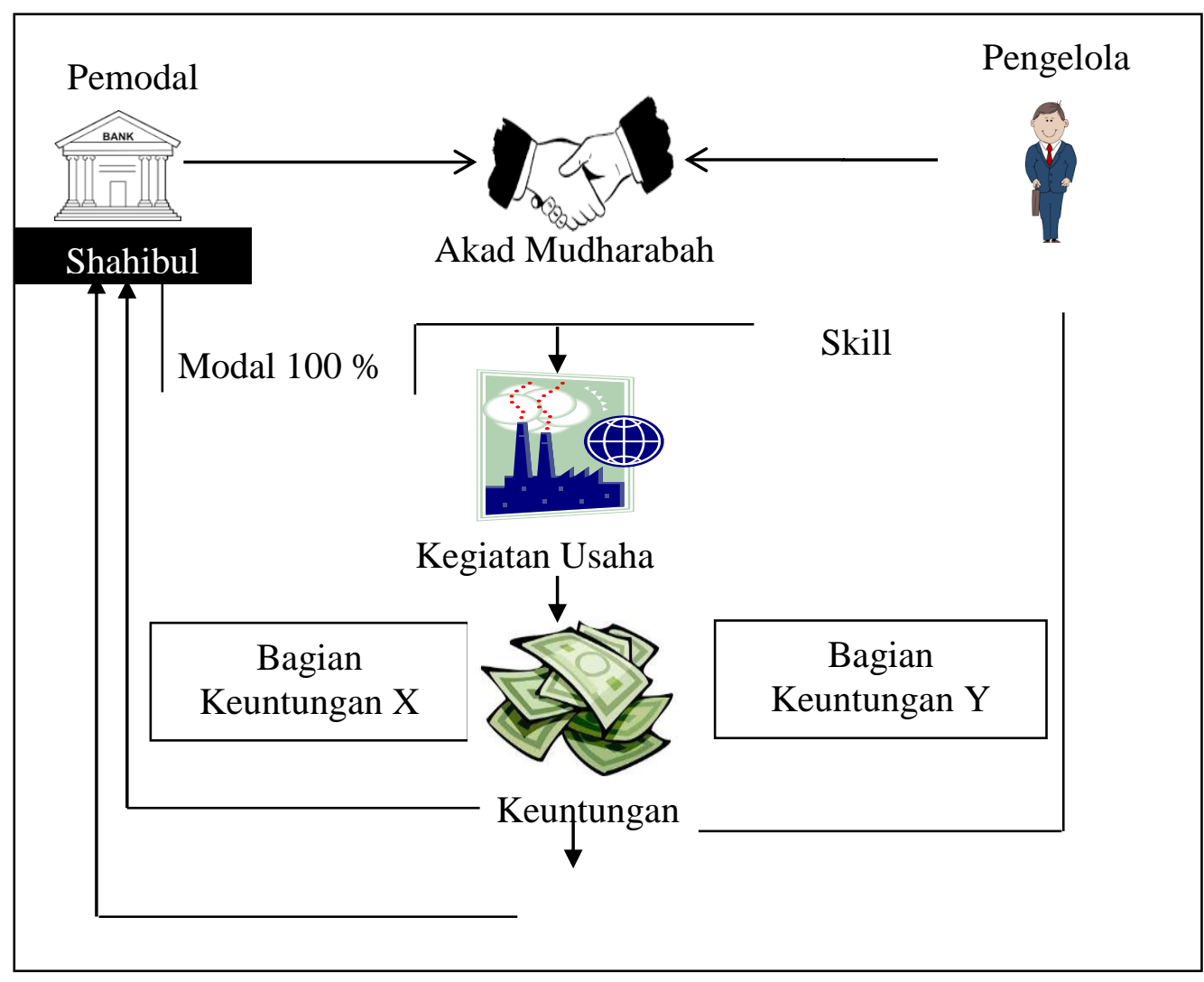

\section{Laba}

Perusahaan selalu berfokus untuk menghasilkan laba yang semaksimal mungkin laba tersebut akan dapat dilihat dari laporan keuangan perusahaan. Menurut Pura (2013, hal.88) laba adalah "laporan yang menunjukkan kemampuan perusahaan dalam menghasilkan keuntungan selama suatu periode tertentu".
Menurut Hani (2014,hal. 81) laba merupakan "hasil aktivitas operasi yang mengukur perubahan kekayaan pemegang saham selama satu periode dan mencerminkan kemampuan perusahaan menghasilkan keuntungan".

Jenis - jenis Laba

Laba pada laporan keuangan dapat diklasifikasikan menjadi beberapa jenis 
bagian. Menurut Lyn M Fraser (2008: 127) mengklasifikasikan laba yaitu sebagai berikut:

\section{1) Laba Kotor}

Perbedaan antara penjualan bersih dan persentase beban pokok penjualan. Langkah pertama dari pengukuran laba pada laporan laba rugi banyak tahap dan merupakan suatu alat analitik kunci dalam menilai suatu kinerja operasi perusahaan.

2) Laba Operasi

Laba sebelum bunga dan pajak atau EBIT. Merupakan langkah kedua dari penentuan laba pada laporan laba rugi.

3) Laba Bersih

Setelah pertimbangan semua pendapatan dan beban yang dilaporkan selama periode akuntansi.

4) Laba per lembar saham biasa

Laba bersih yang tersedia untuk pemegang saham biasa untuk suatu periode dibagi dengan jumlah rata-rata lembar saham biasa yang beredar.

\section{Kerangka Berpikir}

Kerangka berpikir merupakan modal konseptual tentang bagaimana teori yang digunakan berhubungan dengan berbagai faktor yang telah peneliti identifikasikan sebagai masalah penting. Laporan keuangan menjadi dasar perhitungan dan bahan untuk menganalisis tingkat laba perusahaan. Salah satunya mengetahui target dan tumbuh suatu pembiayaan dari suatu bank.

Pembiayaan yang disalurkan oleh bank sangat berpengaruh terhadap peningkatan laba perusahaan, baik itu pembiayaan murabahah, mudharabah dan musyarakah. Pembiayaan merupakan salah satu aset suatu bank dalam bentuk aktiva. Karna merupakan hal yang paling dominan dalam menghasilkan laba perusahaan. Semakin besar pembiayaan yang diberikan maka semakin banyak juga laba yang dihasilkan.

Tetapi bukan hanya laporan keuangan saja sebaik bahan pertimbangan baik buruknya keadaan suatu bank, tetapi pelaksanaan pembiayaan yang diberikan oleh bank harus memenuhi sesuai syaratsyarat dan ketentuan berdasarkan prinsip syariah dan Fatwa MUI-DSN kalau tidak akan terkena sanksi dari pihak yang berwenang. Peneliti meneliti tentang pembiayaan mudharabah, bagaimana prosedur dan pelaksanaannya serta meneliti penyebab turunnya laba di tahun 2015 .

Semakin sesuai prosedur pembiayaan yang diberikan bank, maka semakin baiklah reputasi bank dimata/pandangan masyarakat. Pembiayaan mudharabah merupakan pembiayaan yang dapat dikatakan masih minim peminatnya dikarnakan kebanyakan dari pihak kontraktor. Itu terjadi karena pembiayaan mudharabah tiap tahunnya mengalami peningkatan kecuali ditahun 2015. Karena mudharabah merupakan kerja sama bagi hasil. Jika Pembiayaan mudharabah terus meningkat alangkah baiknya bank dalam menjalankan amal usahanya. Dengan begitu bank dianggap mampu menjaga kesejahteraan karyawan dan itu berarti manajemen bank berhasil dalam menjalankan atau mengoperasikan bank tersebut dengan sebaik-baiknya. Maka Analisis Pembiayaan mudharabah dapat digambarkan sebagai berikut: 


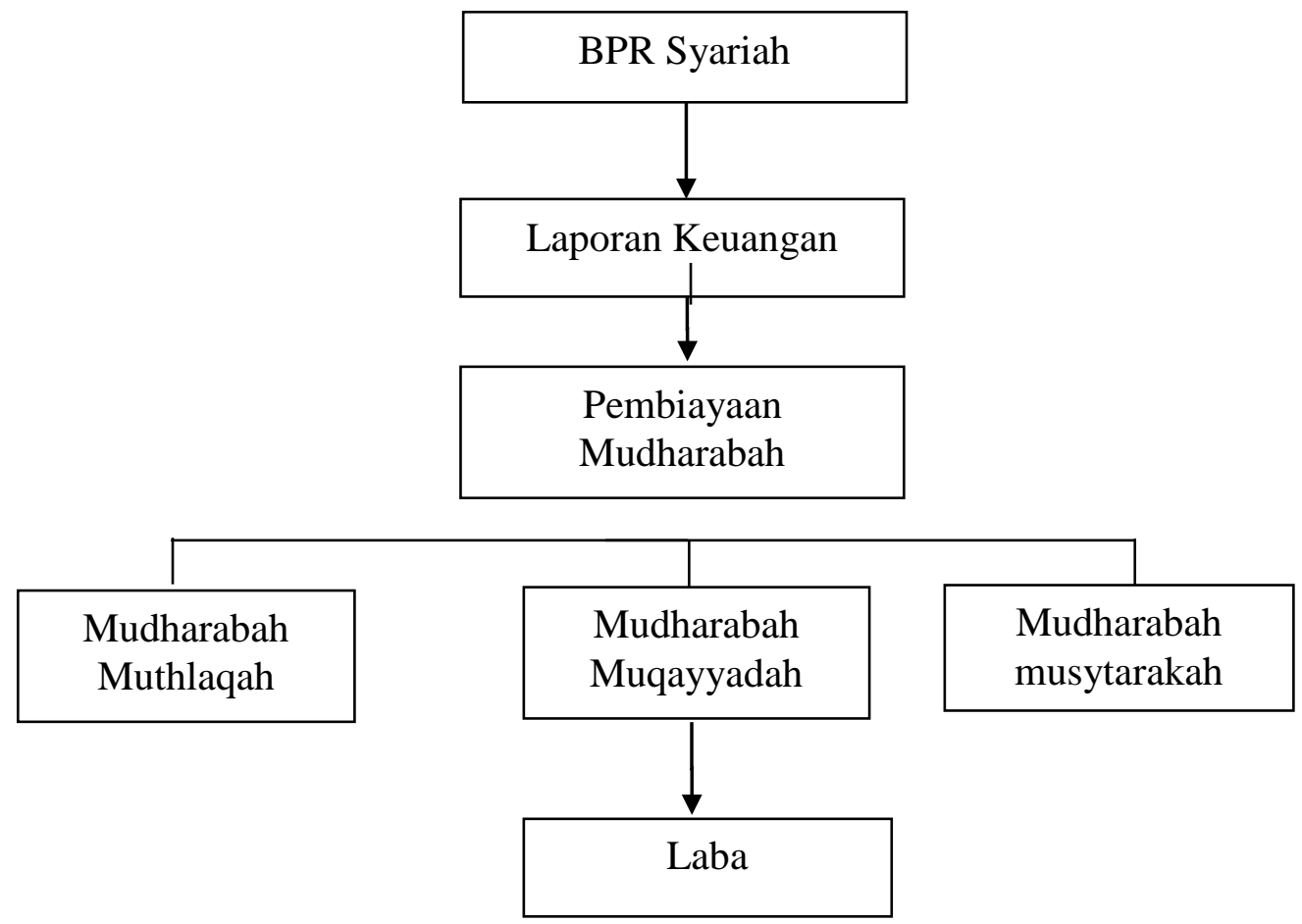

Gambar 3 Kerangka Berfikir

\section{METODE}

Pendekatan penelitian yang digunakan adalah pendekatan deskriptif yaitu penelitian yang berusaha mengumpulkan dan menyajikan data dari perusahaan untuk dianalisis sehingga memberikan gambaran yang cukup jelas atas objek yang diteliti. Menurut Sugiono (2012) statistik deskriptif adalah statistik yang digunakan untuk menganalisis data dengan cara mendeskripsikan atau menggambarkan data yang telah terkumpul sebagai mana adanya tanpa bermaksud membuat kesimpulan yang berlaku untuk umum.

Dalam hal ini yang menjadi variabel penelitian adalah pembiayaan Mudharabah pada PT. Bank Perkreditan Rakyat Syariah Amanah Insan Cita William Iskandar Medan. Mudharabah adalah bentuk kerja sama antara dua belah pihak atau lebih dimana pemilik modal mempercayakan sejumlah modal kepada pengelola dengan suatu perjanjian pembagian keuntungan.
Bentuk ini menegaskan kerja sama dalam paduan $100 \%$ modal kas dari pemilik modal dan keahlian dari pengelola. (1) Mudharabah muthlaqah adalah mudharabah dimana pemilik dana memberikan kebebasan kepada pengelola dana dalam pengelolaan investasinya. (2) Mudharabah muqayyadah adalah mudharabah dimana pemilik dana memberikan batasan kepada pengelola dana,antara lain mengenai tempat, cara dan atau obyek investasi. (3) Mudharabah musytarakah adalah bentuk mudharabah dimana pengelola dana menyertakan modal atau dananya dalam kerjasama investasi.

\section{Jenis data}

Jenis data yang dipergunakan peneliti dalam penelitian ini adalah data kuantitatif data yang berupa laporan keuangan pembiayaan Mudharabah secara langsung diperoleh dari Narasumber (sumber utama) guna untuk memperoleh atau 
mengumpulkan keterangan-keterangan untuk selanjutnya diolah sesuai dengan kebutuhan penelitian. Dalam hal ini data langsung diperoleh dari PT. Bank Perkreditan Rakyat Syariah Amanah Insan Cita William Iskandar Medan.

\section{Teknik Analisis Data}

Pada penelitian ini penulis menggunakan Teknik Analisis Trend. Menurut Hani (2015, hal. 97) menyatakan bahwa "Analisis Tren adalah analisis perbandingan laporan keuangan yang dilakukan dengan cara menelaah neraca, laporan laba rugi, dan laporan arus kas yang berurutan dari satu periode ke periode berikutnya, meliputi perubahan saldo setiap perkiraan dari tahun ke tahun. Hal serupa Kasmir (2008, hal. 82) mengemukakan bahwa "Analisis tren atau trendensi merupakan analisis laporan keuangan yang biasanya dinyatakan dalam bentuk persentase tertentu".

Menurut Prasetya (2005, hal. 27) "Analisis Trend adalah perkiraan-perkiraan dalam suatu laporan keuangan tertentu selama beberapa tahun, biasanya 5 sampai 10 atau 20 tahun".

Dari hasil defenisi diatas dapat disimpulkan bahwa Analisis Trend merupakan suatu alat atau teknik dengan membandingkan laporan keuangan. Masingmasing pos dapat mengalami perubahan dimana perubahan tersebut cukup untuk dianalisis lebih lanjut. Karena dengan analisis tersebut kenaikan atau penurunan dapat diketahui dari masing-masing pos.

Peneliti menganalisis data dengan menggunakan Teknik Analisis Trend untuk melihat kecenderungan pada perusahaan apakah mengalami peningkatan, penurunan, atau tetap dalam pembiayaan Mudharabah untuk menghasilkan laba perusahaan.

Analisis Trend dinyatakan dalam persentase yang merupakan metode analisis untuk mengetahui kondisi keuangan perusahaan, yaitu apakah menunjukkan peningkatan atau penurunan pembiayaan Mudharabah dalam meningkatkan laba.

Adapun rumus untuk menghitung trend sebagai berikut:

$$
\begin{array}{r}
\text { Trend Angka Indeks }=\frac{\text { Tahun Pembanding }}{\text { Tahun Dasar }} \\
\text { Pembiayaan }
\end{array} \quad \begin{gathered}
\text { mudharabah } \\
\text { dan }
\end{gathered}
$$

lababerdasarkan data-data laporan keuangan perusahaan yaitu neraca dan laba rugi.

\section{HASIL DAN PEMBAHASAN Hasil}

Dalam implementasi pembiayaan mudharabah, BPRS Amanah Insan Cita Medan memposisikan diri sebagai mitra kerja yaitu sebagai penyedia dana untuk memenuhi kebutuhan modal nasabah, sehingga posisi BPRS Amanah Insan Cita dengan nasabah adalah sejajar, sesuai dengan Fatwa No. 07/-DSN_MUI/IV/2000.

Sedangkan hasil keuntungan akan dibagikan dengan porsi bagi hasil yang telah disepakati bersama. Apabila terjadi kerugian maka kerugian dalam bentuk uang ditanggung oleh pihak BPRS Amanah Insan Cita, sedangkan nasabah akan menanggung kerugian dalam bentuk kehilangan usaha, nama baik (reputasi) dan waktu.

\section{Pelaksanaan Pembiayaan mudharabah}

Prosedur pembiayaan mudharabah diawali dengan pengajuan permohonan yang harus ditempuh oleh debitur yaitu dengan cara calon nasabah datang kekantor BPRS Amanah Insan Cita Medan. Dan jika persyaratan-persyaratan yang ditentukan oleh pihak bank dapat dipenuhi oleh nasabah dan pihak bank juga menyetujuinya, maka pembiayaan tersebut bisa dilakukan.

Produk pembiayaan yang ditawarkan oleh BPRS Amanah Insan Cita Medan salah satunya adalah pembiayaan mudharabah. Karena pembiayaan mudharabah ini merupakan pola pembiayaan yang sagat penting dalam syariat islam, dimana sistem ini telah dicontohkan oleh rasulullah SAW, yang seharusnya sistem ini yang mendominasi dari kegiatan usaha-usaha 
berbasis syariah, karena disatu pihak dimana banyak orang yang memiliki dana namun tidak mempunyai keahlian/skill, waktu dan pengalaman. Sedangkan pihak lainnya banyak juga orang yang mempunyai keahlian/skill, waktu dan pengalaman namun tidak memiliki dana atau kekurangan dana untuk mengembangkan pemikiran atau keahliannya sehingga pembiayaan ini sangatlah penting baginya untuk mengembangkan keahlian/skillnya tersebut.

Pembiayaan mudharabah adalah akad kerjasama suatu usaha antara dua belah pihak dimana pihak pertama (shahibul mal/Bank) menyediakan seluruh modalnya, untuk diamankan kepada orang pihak kedua (mudharib/nasabah) yang bertindak sebagai pengola, dan keuntungan dibagi sesuai dengan kesepakatan yang disepakati dalam kontrak.

Berdasarkan hasil penelitian yang dilakukan oleh peneliti bahwasanya BPRS Amanah Insan Cita Medan tidak memberikan seluruh dana yang dibutuhkan oleh nasabah dalam melakuka usahanya. BPRS Amanah Insan Cita hanya memberikan pembiayaan pada nasabah yang usahanya sudah berjalan minimal 1 (satu) tahun keatas atau dengan kata lain BPRS Amanah Insa Cita hanya memenuhi kekurangan dalam pengembangan suatu usaha nasabah. BPRS Amanah Insa Cita melakukan hal tersebut untuk menghindari resiko yang terlalu besar apabila memberikan sepenuhnya modal kepada para nasabah yang melakukan permohonan dana, sedangkan usaha yang belum pernah berjalan masih dalam rancangan pihak BPRS Amanah Insa Cita tidak berkenan memberikan permodalan pembiayaan dengan akad mudharabah. Hal ini tentunya tidak sesuai dengan apa yang dinyatakan dalam Fatwa Dewan Syariah Nasional (DSN) dan teori prosedur pmbiayaan yang menyatakan shahibul mal (Bank) sepenuhnya menyediakan dana yang digunakan mudharib (nasabah) selaku pengelola dana.

Dalam penerapan pembiayaan mudharabah yang dilakukan oleh BPRS Amanah Insa Cita, khususnya dalam menyelesaikan suatu masalah apabila sewaktu waktu terjadi kerugian yang disebabkan oleh nasabah, maka pihak BPRS tetap mengenakan ganti rugi terhadap pokok yang dipinjam, dan jaminan yang telah diberikan oleh nasabah tersebut sewaktu waktu bisa dijual oleh pihak BPRS, sebagai antisipasi yang digunakan pleh pihak BPRS tetapi dengan catatan saling ikhlas atau pihak pengelola modal setuju bahwa pihak BPRS dapat menjual jaminan tersebut.

Pembiayaan BPRS Amanah Insa Cita sangat dipengaruhi oleh pendapatan rill nasabah, selama menjalankan kegiatan usahanya, pada saat nasabah menjalankan usaha atau bisnisnya maka pihak BPRS Amanah Insa Cita selalu mengawasi (memonitoring). Hal tersebut dilakukan oleh bank agar pihak bank dapat mengetahui proses usaha sampai pendapatan rill yang diperoleh nasabah serta transaksi-transaksi yang dilakukan nasabah dapat dicatat dan didokumentasikan hal ini untuk menghindari manipulasi laporan yang dilakukan nasabah. Namun tak ada yang dapat memastikan usaha itu akan selalu untung. Untung atau rugi, itu hal yang biasa dalam berusaha. Lalu bagaimana kalau usaha rugi? Karena untung dibagi bersama, maka kerugian pun dibagi bersama pula, itulah letak keadilan dari sistem bagi hasil.

\section{Aalisis Data}

Tabel 2 Pembiayaan Mudharabah periode 2011-2015

\begin{tabular}{|c|c|}
\hline Tahun & Mudharabah \\
\hline 2011 & Rp. 100.000 .000 \\
\hline 2012 & Rp. 181.000 .000 \\
\hline 2013 & Rp. 302.000 .000 \\
\hline 2014 & Rp. 756.642 .000 \\
\hline 2015 & Rp. 615.000 .000 \\
\hline Sumber : PT. Bank Perkreditan Rakyat Syariah Amanah Insan Cita
\end{tabular}




\section{a. Pembiayaan mudharabah}

Rumus untuk menghitung trend sebagai berikut :

Trend Angka Indeks $=\frac{\text { Tahun Pembanding }}{\text { Tahun Dasar }} X 100 \%$

Untuk periode tahun dasar 2011, didapat:

Indeks pembiayaan Mudharabah 2011

$$
\begin{aligned}
& =\frac{100.000 .000}{100.000 .000} \times 100 \% \\
& =100 \%
\end{aligned}
$$

Indeks pembiayaan Mudharabah 2012

$$
\begin{aligned}
& =\frac{180.000 .000}{100.000 .000} \times 100 \% \\
& =180 \%
\end{aligned}
$$

Indeks pembiayaan Mudharabah 2013

$$
\begin{aligned}
& =\frac{302.000 .000}{180.000 .000} \times 100 \% \\
& =167,78 \%
\end{aligned}
$$

Indeks pembiayaan Mudharabah 2014

\begin{tabular}{|c|c|c|c|c|}
\hline Tahun & Pendapatan & & Beban & Laba Bersih \\
\hline 2011 & $\mathrm{Rp} \quad 614.147 .000$ & $\mathrm{Rp}$ & 481.166 .000 & Rp 13.,981.000 \\
\hline 2012 & $\mathrm{Rp} \quad 770.651 .000$ & $\mathrm{Rp}$ & 753.890 .000 & Rp 16.761 .000 \\
\hline 2013 & Rp 1.119.437.000 & $\mathrm{Rp}$ & 818.828 .000 & Rp 275.465.000 \\
\hline 2014 & $\mathrm{Rp} 1.497 .581 .000$ & $\mathrm{Rp}$ & 1.127 .738 .000 & Rp 325.308 .000 \\
\hline 2015 & $\mathrm{Rp} 1.928 .561 .000$ & $\mathrm{Rp}$ & 1.445 .564 .000 & Rp 430.300.000 \\
\hline Total & Rp 5.930.377.000 & $\mathrm{Rp}$ & 4.627 .186 .000 & Rp 1.047 .834 .000 \\
\hline
\end{tabular}

$$
\begin{aligned}
& =\frac{756.642 .000}{302.000 .000} \times 100 \% \\
& =250,54 \%
\end{aligned}
$$

Indeks pembiayaan Mudharabah 2015

$$
\begin{aligned}
& =\frac{615.000 .000}{756.642 .000} \times 100 \% \\
& =81,28 \%
\end{aligned}
$$

Tabel 3. Laba Bersih Periode 2011-2015

Rumus untuk menghitung trend sebagai berikut:

Trend Angka Indeks $=\frac{\text { Tahun Pembanding }}{\text { Tahun Dasar }} X 100 \%$

Untuk periode tahun dasar 2011, didapat:

Indeks Laba Bersih $2011=\frac{13.981 .000}{13.981 .000} \times 100 \%$

$$
=100 \%
$$

Indeks Laba Bersih $2012=\frac{16.761 .000}{13.981 .000} \times 100 \%$

$$
=119,88 \%
$$

Indeks Laba Bersih $2013=\frac{275.465 .000}{16.761 .000} \times 100 \%$

$$
=1.643,49 \%
$$

Indeks Laba Bersih $2014=\frac{325.308 .000}{275.465 .000} \times 100 \%$

$$
=118,09 \%
$$

Indeks Laba Bersih $2015=\frac{430.300 .000}{325.308 .000} \times 100 \%$

$$
=132,27 \%
$$

\section{Pembahasan}

\section{a. Mudharabah}

1. Untuk tahun dasar 2011, didapat

T. $2011=\frac{\text { Rp. } 100.000 .000}{\text { Rp. } 100.000 .000} \times 100 \%$

$$
=100 \%
$$

Untuk pembiayaan ditahun 2011 adalah 100 $\%$ karena sebagai titik awal pembiayaan.

2. Untuk tahun 2012, didapat

T.2012

$$
\begin{aligned}
& =\frac{\text { Rp. } 181.000 .000}{\text { Rp. } 100.000 .000} \times 100 \% \\
& =181 \%
\end{aligned}
$$

Pembiayaan ditahun 2012 mengalami peningkatan sebesar $181 \%$. Hal ini dapat dilihat dari data tahun 2011 dan data tahun 2012.

3. Untuk tahun 2013, didapat

$$
\begin{aligned}
\text { T. } 2013= & \frac{\text { Rp. } 302.000 .000}{\text { Rp. } 181.000 .000} \times 100 \% \\
& =166,85 \%
\end{aligned}
$$

Ditahun ini pembiayaan menurun sebesar $166,85 \%$ akan tetapi tidak berdampak buruk 
bagi pembiyaan karena masih diatas titik $100 \%$.

4. Untuk tahun 2014, didapat

$$
\begin{aligned}
& \text { T. } 2014=\frac{\text { Rp. } 756.642 .000}{\text { Rp. } 302.000 .000} \times 100 \% \\
& =250,54 \%
\end{aligned}
$$

Pada tahun 2014 ini pembiayaan meningkat drastis berlipat ganda dari pembiayaan sebelumnya yang sebesar $250,54 \%$.

5. Untuk tahun 2015, didapat

$$
\begin{aligned}
\text { T. } 2015= & \frac{\text { Rp. } 615.000 .000}{\mathrm{Rp} .256 .647 .000} \times 100 \% \\
& =81,28 \%
\end{aligned}
$$

Pembiayaan pada tahun 2015 sangat menurun karena pembiayaan mengalami penurunan sebesar $81,28 \%$. Karena nominal tersebut dibawah titik dasar pembiayaan yaitu dibawah $100 \%$.

\section{b. Laba Bersih}

1. Untuk tahun dasar 2011, didapat

T. 2011

$$
\begin{aligned}
= & \frac{\mathrm{Rp} \cdot 13.981 .000}{\mathrm{Rp} \cdot 13.981 .000} \times 100 \% \\
& =100 \%
\end{aligned}
$$

Perolehan laba ditahun 2011 sebesar 100\% karena sebagai awal perolehan laba.

2. Untuk tahun 2012, didapat

T. 2012

$$
\begin{aligned}
= & \frac{\text { Rp. } 16 \cdot 261 \cdot 000}{\text { Rp. } 13 \cdot 981 \cdot 000} \times 100 \% \\
& =119,88 \%
\end{aligned}
$$

Ditahun 2012 mengalami peningkatan laba sebesar $119,88 \%$.

3. Untuk tahun 2013, didapat

$$
\begin{aligned}
\text { T. } 2013= & \frac{\text { Rp. } 275.465 .000}{\text { Rp. } 16.261 .000} \times 100 \% \\
& =1.643,49 \%
\end{aligned}
$$

Pada tahun 2013 laba yang diperoleh mengalami peningkatan laba yang sangat tinggi yaitu sebesar $1.643,49 \%$.

4. Untuk tahun 2014, didapat

$$
\begin{aligned}
\text { T. } 2014= & \frac{\text { Rp. } 325.308 .000}{\text { Rp. } 275.465 .000} \times 100 \% \\
& =118 \%
\end{aligned}
$$

Pada tahun 2014 mengalami penurunan laba sebesar $118 \%$. Meskipun menurun tetapi masih diatas $100 \%$.

5. Untuk tahun 2015, didapat

$$
\begin{aligned}
\text { T. } 2015= & \frac{\text { Rp. } 430.000}{\text { Rp. } 325.308} \times 100 \% \\
& =132,27 \%
\end{aligned}
$$

Pada tahun 2015 kembali mengalami peningkatan laba yaitu sebesar 132,27\%.

\section{Pembiayaan mudharabah dalam meningkatkan laba bersih}

Pembiayaan mudharabah dan laba pada tahun 2011:

T. $2011($ pembiayaan $)=\frac{\text { Rp. } 100.000 .000}{\text { Rp. } 100.000 .000} \quad \mathrm{X}$ $100 \%$

$$
\begin{aligned}
& =100 \% \\
& =\frac{\text { Rp. } 13.981 .000}{\text { Rp. } 13.981 .000} \times 100 \% \\
& =100 \%
\end{aligned}
$$

T.2011 (Laba)

Pembiayaan mudharabah dan laba bersih pada tahun 2011 adalah 100\% karena sebagai titik awal pembiayaan dan juga titik awal perolehan laba.

Pembiayaan mudharabah dan laba pada tahun 2012:

T. $2012($ pembiayaan $)=\frac{\text { Rp.181.000.000 }}{\text { Rp.100.000.000 }} x$

$100 \%$

T.2012 (Laba)

$$
\begin{aligned}
& =181 \% \\
& =\frac{\text { Rp. } 16 \cdot 261 \cdot 000}{\text { Rp. } 13 \cdot 981 \cdot 000} \times 100 \% \\
& =119,88 \%
\end{aligned}
$$

Pembiayaan mudharabah pada tahun 2012 mencapai $180 \%$ dan laba yang dihasilkan juga meningkat yaitu sebesar 119,88\%.

Pembiayaan mudharabah dan laba pada tahun 2013:

T. $\begin{aligned} 2013(\text { pembiayaan }) & =\frac{\text { Rp. } 302.000 .000}{\mathrm{Rp} .181 .000 .000} \times 100 \% \\ & =166,85 \%\end{aligned}$

$$
\begin{aligned}
\mathrm{T} .2013 \text { (Laba) } & =\frac{\text { Rp. } 275.465 .000}{\mathrm{Rp} .16 .761 .000} \times 100 \% \\
& =1.643,49 \%
\end{aligned}
$$

Pembiayaan mudharabah pada tahun 2013 mengalami penurunan yaitu sebesar $166,85 \%$. Meskipun pembiayaan menurun tetapi laba yang dihasilkan sangat tinggi dan mencapai $1.643,49 \%$.

Pembiayaan mudharabah dan laba pada tahun 2014:

$$
\begin{array}{lll}
\text { T. } 2014 \text { (pembiayaan) } & =\frac{\text { Rp.756.642.000 }}{\text { Rp.302.000.000 }} & \text { x } \\
100 \%=250,54 \% & \\
\text { T.2014 (Laba) } & =\frac{\text { Rp. } 325 \cdot 308 \cdot 000}{\text { Rp.275.465.000 }} & \text { X }
\end{array}
$$$$
100 \%=118 \%
$$ 
Pada tahun 2014 pembiayaan mudharabah mengalami peningkatan yang tinggi yaitu sebesar 250,54\%. Tetapi laba yang dihasilkan mengalami penurunan, meskipun laba menurunmenjadi $118 \%$, masih dikatagorikan stabil karena masih diatas $100 \%$.

Pembiayaan mudharabah dan laba pada tahun 2015:

T. 2015 (pembiayaan) $=\frac{\text { Rp.615.000.000 }}{\text { Rp.256.647.000 }} \quad \mathrm{x}$ $100 \%=81,28 \%$

T.2015 (Laba) $=\frac{\text { Rp. } 430.300 .000}{\text { Rp.325.308.000 }}$

$\mathrm{x}$

$$
100 \%=132,27 \%
$$

Pembiayaan mudharabah pada tahun 2015 sangat jauh menurun dibawah $100 \%$ yaitu sebesar $81,28 \%$, akan tetapi meskipun pembiayaan menurun, laba yang diperoleh mengalami peningkatan yaitu sebesar $132.27 \%$.

\section{Pembahasan}

1. Pembiayaan dan laba bersih pada tahun 2011 adalah titik awal pembiayaan dan laba, hal ini didapat dari data tahun 2011.

2. Penyaluran pembiayaan mudharabah pada tahun 2012 mencapai $181 \%$ dan laba yang dihasilkan pun meningkat sebesar $118,88 \%$. Hal ini dapat dilihat pembiayaan dan laba pada tahun 2012.

3. Pembiayaan mudharabah dalam menghasilkan laba tetap berjalan walaupun pembiayaan mudharabah menurun menjadi $167,78 \%$. Laba yang diperoleh meningkat pesat sebesar $1.643,49 \%$. Hal ini dapat dilihat dari data pembiayaan dan laba pada tahun 2013.

4. Ditahun 2014 didapat hasil yang berbeda, dikarenakan ditahun 2014, pembiayaan mudharabah meningkat tinggi menjadi sebesar 250,54\%. Walaupun pembiayaan mudharabah meningkat tetapi laba yang dihasilkan menurun sebesar $118 \%$. Hal ini dpat dilihat pada data pembiayaan dan laba pada tahun 2014.

5. Pada tahun 2015 pembiayaan mudharabah kembali menurun dan penurunan pembiayaan ini sangat jauh sebesar 81,28\%. Walaupun didalam pembiayaan mengalami penurunan, tetapi laba mengalami peningkatan sebesar $132,27 \%$.

\section{REFERENSI}

Ali, Zainuddin 2010. Hukum Perbankan Syariah. edisi 1 Cet. 2 Jakarta: Sinar Grafika.

Baridwan, Zaki, 2014. Intermediate Accounting. Yogyakarta : BPFEYogyakarta.

Freser, M Lyn dan Aileen Ormiston, 2008. Memahami Laporan Keuangan Indonesia. Jakarta : PT Indeks Grafindo Persada.

Hani, Syafrida, 2014. Teknik Analisis Laporan Keuangan. Jakarta : In Media Insani

http://www.ojk.go.id/id/kanal/perbankan/dat a-dan-statistik/laporan-keuanganperbankan/Default.aspx

Ismail, 2013. Perbankan Syariah. Jakarta : PT. Fajar Interpratama Mandiri, Kencana Prenada Media Group.

Kasmir, 2008. Bank dan Lembaga Keuanga $n$ Lainnya. Jakarta PT. Raja Grafindo Persada

Latumaerissa, Julius R, 2012. Bank Dan Lembaga Keuangan Lain. Jakarta : Salemba Empat

Lubis, Suhrawardi K dan Wajdi Farid. Hukum Ekonomi Islam. Jakarta :Sinar Grafika

Muhammad,2014.

Manajemen Dana Bank Syari'ah.

PT. Rajagrafindo Persada

Pura, Rahman 2013 Pengantar Akuntansi 1, PT Gelora Aksara Pratama

Rivai, Veitzhal dan Andi, Buchari, 2009. Islamic Economics Syariah Bukan Opsi Tapi Solusi. Ed. 1. Cet.1. Jakarta : Bumi Aksara.

----Bank And Financial Institution Management Conventional \& Syar'i 
System. Jakarta : PT. Raja B Grafindo Persada

Rodoni, Ahmad dan Hamid, Abdul 2008. Lembaga Keuangan Syariah. Jakarta: Aksara

Soemitra, Andri 2010. Bank dan Lembaga Keuangan Syariah. Jakarta : Kencana.

Sugiono, 2012 . Metode Penelitian Penelitian. Alfabeta : Bandung

Susiana. 2010. Analisis Pembiayaan Mudharabah Pada PT. Bank Tabungan (Persero) TBK Kantor Cabang Syariah Malang. Malang : UIN Malang.

Umam,Khaerul, 2013. Manajemen Perbankan Syariah, Pustaka Setia. Bandung.

Undang-Undang Nomor 21 Tahun 2008

Untung, Budi, 2005. Kredit Perbankan Di Indonesia. Ed. II Yogyakarta : Andi 